\title{
Populasjons-basert kreftregister i etiologisk forskning; illustrert ved studier basert på kobling mellom høyde- og vektdata og Kreftregisteret
}

\author{
Steinar Tretli ${ }^{1,2}$ og Trude Eid Robsahm ${ }^{1}$ \\ 1) Institutt for populasjons-basert kreftforskning, Kreftregisteret, Oslo \\ 2) Institutt for samfunnsmedisin, Norges Teknisk-Naturvitenskapelige Universitet, Trondheim \\ Korrespondanse: Steinar Tretli, Institutt for populasjons-basert kreftforskning, Kreftregisteret, Montebello, 0310 Oslo \\ Telefon: 23333960 Telefax: 22451370 e-post: steinar.tretli@kreftregisteret.no
}

\begin{abstract}
SAMMENDRAG
Populasjons-baserte kreftregistre gir oss mulighet til overvåke utbredelsen av kreftsykdommer i en klart definert populasjon. Denne informasjonen kan analyseres alene, hvor man beregner insidens- og mortalitetsrater og sammenligner disse i forhold til variable som kjønn, alder og geografiske områder. Hvis man i tillegg kobler kreftregisterdata mot andre datakilder gir dette et billig grunnlag for etiologisk kreftforskning. I denne forskningen brukes i hovedsak to typer design: kasus-kontroll og kohorte-studier, og i denne sammenhengen er den sistnevnte mest egnet. Denne studien har til hensikt å illustrere bruken av et populasjons-basert kreftregister i etiologisk forskning, med tilhørende fordeler og ulemper.

Generelt i kohorte-studier måler man en aktuell eksponering blant et stort antall friske personer som følges til et angitt endepunkt. Deretter analyseres forskjeller i insidens mellom de ulike eksponeringsnivåer. Imidlertid, er det mange innfallsvinkler til slike studier. Det Norske Kreftregisteret registrerer systematisk mer enn 40 ulike kreftformer, noe som åpner for muligheten til å følge opp eksponeringsdata for de samme personene med hensyn til flere kreftformer. For å illustrere slik forskning presenterer vi flere koblingsstudier mellom Kreftregisteret og høyde- og vektdata fra en obligatorisk skjermbilde-undersøkelse for tuberkulose i Norge, i perioden 1963-74.
\end{abstract}

\section{Tretli S, Robsahm TE. The applicability of a population-based cancer registry in etiological research. Nor J Epidemiol 2004; 14 (1): 85-90.}

\section{ENGLISH SUMMARY}

Population-based cancer registries hold information on the distribution of cancer in well-defined populations, and are thereby important resources for studies in cancer epidemiology. The information may be analysed without the need for any additional data collection. Cancer site-specific incidence rates, as well as mortality rates, can be calculated and compared according to variables such as age, sex and geography. However, linking this information with other data sources gives basis for etiological cancer research in an economical way. The two main designs used are case-control and cohort studies, where cohort design is most suitable in this connection. The objective of the present study is to illustrate the use of a populationbased cancer registry in etiological coupling studies, presenting both advantages and disadvantages.

Generally, in a cohort study, the exposure in focus is measured in a large number of healthy people, who are followed-up until a defined endpoint. Subsequently, statistical analyses demonstrate whether variations in incidence exist between the different levels of exposure. However, several approaches are used to carry out such studies. The Norwegian Cancer Registry has a compulsory reporting system and it collects information about more than 40 different cancer types. This facilitates the possibility to investigate whether an exposure in focus is associated with several types of cancer. To exemplify this, we are presenting studies based on a linkage between the Cancer Registry and height- and weight data, collected in a nationwide screening for tuberculosis in Norway during the period from 1963 to 1974.

\section{INTRODUKSJON}

Et av de viktigste historiske eksempler på etiologisk kreftforskning er studiene til Bernardino Ramazzini (1633-1714). Han viste blant annet at brystkreft forekom oftere hos nonner enn hos andre kvinner; en av flere observasjoner som senere har knyttet brystkreft til hormoner. I løpet av de neste 200 år ble det bare presentert noen få epidemiologiske studier, men de viste klare sammenhenger mellom ulike eksponeringer og kreftforekomst i ulike organer. Flere av disse observasjonene var knyttet til eksponeringer gjennom arbeid, som for eksempel Potts studie om økt forekomst av kreft i skrotum hos feiere i London (Pott 1775).

Etter hvert ble det klart at hvis man skulle komme videre i årsaksforskningen, måtte man få oversikt over 
hvilke personer i en befolkning som får kreftsykdommer. Dette var tanken bak å opprette kreftregistre for klart definerte populasjoner. Det første populasjonsbaserte kreftregisteret ble opprettet i Hamburg (Tyskland) i 1926, men en ny era regnes vanligvis fra 1940tallet, da flere registre etter hvert tok form. I 1940 ble et begrenset, men populasjons-basert register, opprettet i New York, initiert av National Cancer Institute. Året etter ble et kreftregister i Connecticut opprettet, og i 1942 fulgte det Danske Kreftregisteret som er det eldste av de nasjonale registrene. Helsedirektoratet, Statistisk sentralbyrå, Radiumhospitalet og Landsforeningen mot Kreft stod bak etableringen av det Norske Kreftregisteret, som ble opprettet i 1951. Som en kuriositet kan det nevnes at et norsk kreftregister ble startet så tidlig som i 1907, og dette eksisterte i nærmere 20 år. Senere, på 1950-tallet, dukket det opp kreftregistre i flere land, men de fleste var ikke nasjonale. I 1966 var det i alt 32 kreftregistre som kunne presentere data av akseptabel kvalitet. Alle disse registrene ga etter hvert anledning til å sammenligne kreftforekomst mellom kjønn, aldersgrupper og geografiske områder. Akkumulering av data over tid har også gitt mulighet til å studere kreftforekomsten over tid.

De første register-baserte studiene var hovedsakelig av deskriptiv art, men etter hvert dukket det også opp studier hvor personers livsstil kunne kobles mot kreftregistrene (etiologisk forskning). I Norge ble slike koblingsstudier enklere og mer aktuelle ved innføringen av unikt fødselsnummer for alle som var i live $\mathrm{i}$ 1960, eller som er født etter den tid. Entydig personidentifikasjon og komplette kreftregistre, i Norge og de øvrige nordiske land, setter oss i en privilegert stilling med hensyn til kvalitet, arbeidsmengde og kostnader $\mathrm{i}$ forhold til forskningen.

Formålet med denne artikkelen er å illustrere bruken av et populasjons-basert kreftregister i etiologisk forskning, med dets fordeler og ulemper.

\section{STUDIEDESIGN: KASUS-KONTROLL OG KOHORTE-STUDIER}

I etiologisk kreftforskning brukes i hovedsak to typer design: 1) Kasus-kontroll og 2) Kohorte-studier. Kasus-kontroll studiene forutsetter at den eksponeringsvariabel som studeres, skal måles både hos kasus og tilhørende kontroll på diagnosetidspunktet. Deretter undersøker man om det er forskjeller i eksponeringsgrad mellom de to gruppene. Allerede forut for diagnosetidspunktet kan den eller de variable vi ønsker å undersøke være påvirket av sykdommen, og måler man eksponeringen på et enda senere tidspunkt, vil noen av kasusene allerede være døde av sykdommen. Dette betyr at opplysninger om eksponering for noen kasus vil måtte erstattes av opplysninger fra familie eller andre som står eller stod vedkommende nært. Denne tilnærmingen kan gi uriktige opplysninger som igjen kan resultere i skjevheter i materialet og feil konklusjoner. Hvor alvorlige følger slike skjevheter gir, avhenger av type eksponeringsvariabel, men også av hvilken krefttype som studeres. Det er derfor i de fleste tilfeller vanskelig å bruke et populasjons-basert kreftregister til å lokalisere kasus. Et annet problem er at store registre har en innebygd forsinkelse som skyldes at de meldepliktige har en viss tid på seg for å sende meldingene, men også fordi det kreves tid for å samordne informasjonen fra de ulike informasjonskildene. Det finnes kun få eksempler på kasus-kontroll studier fra det Norske Kreftregisteret (Grimsrud et al 1998, Ewertz et al 2001).

Derimot finnes det mange eksempler på kohortestudier, hvor populasjons-baserte kreftregistre har hatt betydning. I denne typen studier måles den aktuelle eksponerings-variabelen hos et stort antall "friske" personer som følges til et angitt endepunkt eller tidspunkt. Deretter analyseres forskjeller i insidens mellom ulike eksponeringsnivåer. Det teoretisk beste utgangspunktet for en kohorte-studie er eksistensen av en a priori hypotese, som uttrykker forventet sammenheng mellom en gitt eksponeringsvariabel og en aktuell kreftsykdom. Deretter samler man inn eksponeringsdata for å teste hypotesen. Men utviklingen av en kreftsykdom tar lang tid og sykdommen kan være tilstede lenge for den gir symptomer og blir diagnostisert. Oppfølgingstiden i kreftsammenheng bør derfor være minst 5 år. Den lange oppfølgingstiden gjør det både kostbart og tidkrevende å vente på at hypotesen skal bli avklart. De fleste kohorte-studier gjennomføres derfor ikke på denne måten.

Alternativet er å se etter andre person-identifiserte datakilder som omfatter et stort nok antall personer, og som inneholder direkte eller indirekte informasjon om den eksponering man er ute etter i hypotese-sammenheng, og hvor innsamlingen av disse data ligger noe tilbake i tid. Et eksempel på en slik datakilde er de høyde og vektdata som ble samlet inn i forbindelse med en obligatorisk skjermbilde-undersøkelse for tuberkulose for alle over 15 år, i 17 av våre 19 fylker (Oslo og Buskerud er ikke representert av praktiske grunner), i perioden 1963-74. Studier som er basert på kobling mellom disse høyde og vektdata og Kreftregisteret er brukt til å illustrere denne fremgangsmåten.

I noen tilfeller har man ikke en klart begrunnet a priori hypotese, men driver en hypotese-skapende "fisking" i data. Molekylærbiologisk sett er kreft én sykdom, og det kan derfor være lønnsomt å studere assosiasjonen mellom en eksponeringsvariabel og flere ulike kreftformer, når det eksisterer en bekreftet hypotese for én kreftform. Slike "fiskestudier" er nødvendig i utviklingen av nye hypoteser, men det er en forutsetning at studien presenteres på denne måten. Man mistenker likevel at det i studier, hvor hypotesen genereres etter at resultatet av analysene foreligger, blir presentert som om hypotesen var a priori.

I kohorte-studier, hvor en aktuell eksponeringsvariabel skal måles $i$ et biologisk materiale, vil det være for kostbart å analysere biologiske prøver for en hel populasjon. I slike studier bruker man gjerne et design som kalles nøstet kasus-kontroll. Ved å koble 
biologiske materialer til Kreftregisteret kan man finne alle tilfeller med en aktuell kreftsykdom. Til hvert kasus trekkes en eller flere kontroller fra det samme biologiske materialet. Deretter analyseres kasus og kontroller med hensyn på de variabler som er av interesse. Et slikt design har mange fortrinn: 1) lavere laboratoriekostnader, 2) de samme blodprøvene kan brukes i ulike studier (ulike eksponeringsvariable og ulike kreftformer), 3) krever mindre datakapasitet.

\section{Fordeler}

Det unike fødselsnummeret som er gitt alle norske innbyggere, gjør det enkelt å koble datakilder til Kreftregisteret. Ulike studier har vist at Kreftregisteret er nærmest 100\% komplett for solide svulster (Lund 1981, Helseth et al 1988, Mork et al 1995, Harvei et al 1996). De eneste krefttilfellene vi mister i slike koblinger er de som emigrerer. Men disse kan vi sensurere i den statistiske analysen siden vi kjenner utflyttingsdatoen. Med god oversikt over landets innbyggere er det færre muligheter for at resultatene påvirkes av seleksjon og kvaliteten på studiene øker. Registre som ikke dekker en klart definert populasjon har begrensninger $\mathrm{i}$ å følge personer som flytter inn og ut av nedslagsfeltet for registeret. Dersom muligheten for identifisering likevel foreligger, er dette ofte en kostnadskrevende prosess.

Et register som systematisk registrerer mer enn 40 ulike krefttyper, og innenfor hver krefttype registrerer ulike varianter, åpner for muligheten til å følge opp eksponeringsdata for de samme personene med hensyn på flere kreftformer.

\section{Ulemper}

Dersom en hypotese foreligger, kan denne undersøkes ved hjelp av eksponeringsdata som er samlet inn til andre formål. Men dette kan medføre at man bruker eksponeringsbeskrivelser som ikke er optimale. Resultatet er at man bringer ekstra "støy" inn i målingene. De sammenhenger man eventuelt observerer kan bli svakere enn det de egentlig er (Veierød \& Laake 2000).

Et annet problem knyttet til kohorte-studier er konfundering. Med det menes at en eller flere variable kan ha en mulig årsakssammenheng med den aktuelle sykdommen, og samtidig være statistisk assosiert med den eksponeringsvariabelen vi studerer. I koblingsstudier mangler man ofte målinger av mulige konfunderende variable, eller de kan være målt med en dårligere presisjon enn ønsket. Sammenhengene mellom konfunderende faktor og sykdom, og mellom konfunderende faktor og eksponering skal være sterke før en observert sammenheng mellom eksponering og aktuell kreftsykdom i sin helhet kan forklares gjennom den konfunderende variabelen (Bross 1967). Redselen for konfundering er derfor trolig alt for stor. Generelt i litteraturen ser man at variable som benevnes som mulig konfunderende variable ikke har spesielt sterk sammenheng hverken med den aktuelle sykdommen eller eksponeringsvariabelen.

\section{Administrative bestemmelser}

Det er knyttet en del formelle krav til denne type forskning. Selv om forskningen utføres på avidentifiserte data, forlanges det konsesjon fra Datatilsynet før man kan koble to datakilder, også når disse har konsesjon hver for seg. I tillegg er hovedregelen at deltakerne $\mathrm{i}$ en studie skal samtykke i bruken av dataene. I noen tilfeller er det forutsetning at Sosial- og Helsedirektoratet gir dispensasjon fra taushetsplikten tilknyttet lagrete medisinske data.

Det er også nødvendig å vite når deltakere $\mathrm{i}$ undersøkelser ikke lenger er under observasjon, når de dør eller flytter utenlands. I mange tilfeller er det da ønskelig å koble til dødsdato og eventuelt dødsårsak, men dette krever spesiell tillatelse fra Dødsårsaksregisteret. I noen tilfeller kan det også kreves godkjennelse $\mathrm{i}$ en av de regionale etiske komitéene, eksempelvis hvis forskningen er rettet mot den samiske befolkningen. Den tiden som brukes på skriving og behandling av søknader har nådd et omfang som kan hemme aktiviteten i forskningsmiljøene.

\section{EKSEMPLER PÅ BRUK AV POPULASJONS- BASERT KREFTREGISTER I ETIOLOGISK FORSKNING}

For å gi et innblikk i hva registerbasert forskning kan innebære, presenteres resymé av de publikasjoner som er kommet ut så langt ved å koble høyde og vektdata fra skjermbilde-undersøkelsen til Kreftregisteret. I hovedsak inkluderer disse studiene høyde og vektdata fra kvinner og menn i alderen 30-69 år. For hver enkelt studie vil vi kort beskrive bakgrunn, resultater og kommentere spesielle forhold. I tillegg vil vi angi det antall ganger hver artikkel er sitert $\mathrm{i}$ andre artikler $\mathrm{i}$ internasjonale, indekserte tidsskrifter. Ytterligere to artikler er innsendt for vurdering i internasjonale tidsskrifter og fire andre prosjekt er planlagt og delvis under bearbeidelse.

\section{Insidens- og mortalitetsstudier}

Studie 1: Tretli $S$ (1989) Height and weight in relation to breast cancer morbidity and mortality. A prospective study of 570,000 women in Norway.

Bakgrunn: Østrogen er knyttet til brystkreftutvikling, og østrogen fra andre kilder enn eggstokkene kan være av betydning. Tidligere studier antyder at forskjeller $\mathrm{i}$ kroppsstørrelse kan forklare forskjeller i brystkreftforekomst mellom populasjoner. Denne studien undersøkte hvorvidt forskjeller i høyde og vekt kunne være knyttet til brystkreftsykdom og -død i Norge. Resultater: Høyde og BMI var positivt assosiert med brystkreft, både insidens og mortalitet. Overvektige kvinner over 50 år hadde forhøyet risiko for å få sykdommen, mens det å være overvektig før 50 års alder så ut til å være beskyttende. Kommentarer: Det forelå en a priori hypotese på bakgrunn av flere mindre studier, med til dels inkonsistente funn. Studiens størrelse og muligheten for å analysere både insidens og mortalitet har 
gitt studien ganske stor oppmerksomhet. Artikkelen er trukket fram i en oversiktsartikkel om risikofaktorer for brystkreft i New England Journal of Medicine. Svakheten med studien er mangelen på opplysninger om hvordan andre kjente risikofaktorer er fordelt $\mathrm{i}$ forhold til høyde og kroppsmasse-indeks (BMI). På det tidspunktet da studien ble gjennomført, representerte størrelsen på studien betydelige kapasitetsproblemer i de statistiske analysene. Antall siteringer: 33

Studie 2: Helseth $A$ \& Tretli $S$ (1989) Premorbid height and weight as risk factors for development of central nervous system neoplasms.

Bakgrunn: Utgangspunktet for studien var at man visste lite om risikofaktorer for kreft $\mathrm{i}$ det sentrale nervesystemet (SNS). Kroppsstørrelse var assosiert med flere ulike kreftformer og derfor ønsket forfatterne å se om høyde og vekt, målt før sykdommen ble oppdaget, kunne være assosiert til svulster i SNS. Resultater: Kroppshøyde var positivt assosiert med risiko for svulster i SNS (signifikant for glioblastom hos menn og "andre gliomaer" hos kvinner). BMI var negativt assosiert med andre gliomaer enn glioblastom hos kvinner. Kommentarer: Dette var en "fiskestudie", foreløpig uten særlig betydning i senere forskning. Antall siteringer: 0

Studie 3: Tretli S \& Magnus K (1990) Height and weight in relation to uterine corpus cancer morbidity and mortality. A prospective study of 570,000 women in Norway.

Bakgrunn: Kreft i livmor har vært sterkt knyttet til østrogen-eksponering, som modifiseres av paritet, inntak av hormoner og sannsynligvis av kroppsfett. Studiens design med to endepunkt, sykdom og død, kan indikere i hvilken fase av kreftutviklingen høyde og vekt er av betydning. Resultater: Høyde og BMI var positivt assosiert med livmorkreft, både insidens og mortalitet. Kommentarer: Det forelå en klar hypotese på bakgrunn av tidligere kasus-kontroll studier som har fremhevet betydningen av kroppsstørrelse som risikofaktor. Studiens størrelse og prospektive karakter ga visse muligheter for oppklaringer. Studien har hatt betydning i risikobetraktningene omkring livmorkreft. Antall siteringer: 23

Studie 4: Thune I, Olsen A, Albrektsen G, Tretli S (1993) Cutaneous malignant melanoma: association with height, weight and body-surface area. A prospective study in Norway.

Bakgrunn: Studien ønsket å undersøke hvorvidt risikoen for malignt melanom i hud (CMM) kunne variere med kroppsstørrelse, på bakgrunn av at antall celler under risiko for å bli en kreftcelle kunne være knyttet til kroppens overflateareal. Resultater: Kroppsoverflatearealet var positivt assosiert med CMM. Risikoen for CMM økte med økende kroppshøyde. Tilsvarende $ø$ kte forekomsten med økende BMI blant menn. Blant kvinner gjaldt dette bare for lokalisasjoner på underekstremitetene. Kommentarer: Antropometriske mål var lite studert, og i de studier som forelå var funnene uklare. Hypotesen i studien var bokstavelig talt bygd på "antall celler eksponert" for solstråling. En svakhet med studien var mangel på data som kunne si noe om forskjeller i solingsvaner etter kroppsstørrelse. Antall siteringer: 10

Studie 5: Robsahm TE \& Tretli S (1999) Height, weight and gastrointestinal cancer, a follow-up study in Norway.

Bakgrunn: Kosten i oppveksten er av betydning for kroppshøyde, mens kroppsvekt påvirkes av kostholdet til enhver tid. Kostholdsvariable var antatt å påvirke kreftutvikling i mage og tarmkanalen gjennom flere mekanismer, men hvorvidt høyde og vekt var assosiert med disse kreftformene var uavklart. Resultater: Høyde var positivt assosiert med tykktarmskreft, i mindre grad med kreft i endetarmen. Risikoen for tykk- og endetarmskreft blant menn økte med økende BMI. Mønsteret var mer uklart for kvinner. En svak positiv sammenheng mellom BMI og kreft i galleblæren ble observert for kvinner. Det ble ikke funnet sammenhenger mellom antropometriske mål og kreft i bukspyttkjertelen. Kommentarer: Det eksisterte a priori hypoteser for alle kreftformene i denne studien, bortsett fra for kreft i bukspyttkjertelen. Det mest konsistente funnet var sammenhengen mellom høyde og tykk- og endetarmskreft, som har gitt diskusjon rundt andre forklaringsmodeller enn de som er tilknyttet overvekt. Studiens størrelse har gjort resultatene interessante i forskningsmiljøer. Antall siteringer: 10

Studie 6: Tretli $S$ \& Robsahm TE (1999) Height, weight and cancer of the oesophagus and stomach: a follow-up study in Norway.

Bakgrunn: Tilsvarende som for studien over. Resultater: Lav kroppshøyde var assosiert med kreft i spiserøret. Нøy BMI ble funnet å øke risikoen for adenokarsinom i spiserøret mens lav BMI var assosiert med plateepitelkarsinom i spiserøret og med kreft i magesekken. Disse sammenhengene var til stede også når materialet ble begrenset til krefttilfeller med diagnose minst 5 år etter høyde- og vektmålingene. Kommentarer: Tidligere funn av sammenheng mellom BMI og kreft i spiserøret var uklare. Denne studien viste en mulig årsak; sammenhengen går hver sin vei avhengig av hvilken histologisk type svulsten er. Dette var den første prospektive studie som viste dette, og resultatet er bekreftet i senere studier. Forekomsten av adenokarsinomer i spiserøret har økt sterkt over tid, og det er diskutert hvorvidt dette er en realitet. Våre funn indikerer at insidensøkningen ikke er et artefakt. Antall siteringer: 10

Studie 7: Akre O, Ekbom A, Sparen P, Tretli S (2000) Body size and testicular cancer.

Bakgrunn: Når det gjelder testikkelkreft har kjønnshormoner vært i fokus. Kroppsstørrelse, som også er relatert til flere hormonelle forhold, har endret seg over tid. Spørsmålet var om det var noen sammenheng 
mellom kroppsstørrelse og testikkelkreft. Resultater: Kroppshøyde var positivt assosiert med testikkelkreft, mens BMI var negativt assosiert. Kommentarer: De observerte sammenhengene kan forklares av hormonelle mekanismer; korte og tykke menn har lavere risiko for testikkelkreft på grunn av lavere eksponering av androgene og/eller veksthormoner. Studien peker på at vekstfaktorer tidlig i livet kan være av betydning for utvikling av testikkelkreft. Antall siteringer: 9

Studie 8: Engeland A, Tretli S, Bjørge T (2003) Height, body mass index and prostate cancer: a follow up of 950,000 Norwegian men.

Bakgrunn: Flere studier har sett på sammenhengen mellom antropometriske mål og kreft i prostata, uten entydige resultater. Resultater: Risikoen for prostatakreft ble funnet å øke med økende kroppshøyde. En svakere sammenheng ble observert mellom BMI og prostatakreft, men menn som var fete i 45-årsalderen hadde forhøyet risiko for kreft $\mathrm{i}$ alderen 50-59 år. Kommentarer: Studien viser at inkonsistente resultater i tidligere studier kanskje kan forklares med at BMI har ulik betydning i ulike aldersgrupper; de assosiasjonene man observerer kan være avhengig av hvilke aldersgrupper som studeres. Den sammenhengen man observerer mellom høyde og insidens åpner for at vekstfaktorer tidlig i livet også kan være av betydning for prostatakreft. Antall siteringer: 0 (ny studie)

Studie 9: Engeland A, Tretli S, Bjørge $T$ (2003) Height, body mass index and ovarian cancer: a follow up of 1.1 million Norwegian women.

Bakgrunn: I tidligere studier er BMI både positivt og negativt assosiert med eggstokkreft mens sammenhengen med høyde ikke er undersøkt. Resultater: Kvinner som var overvektige i oppveksten eller i tidlig voksen alder har forhøyet risiko for kreft i eggstokkene. Høyde ble funnet å øke risikoen for kvinner under 60 år. Kommentarer: Studien peker på at forhold i barneog ungdomsårene kan ha betydning for risiko for eggstokkreft senere i livet. Studien viser at inkonsistente sammenhenger mellom BMI og eggstokkreft kan skyldes at man ser på BMI i ulike aldersgrupper, og dermed i ulike hormonelle perioder. Antall siteringer: 0 (ny studie)

\section{Overlevelsesstudier}

Studie 10: Tretli S, Haldorsen T, Ottestad L (1990) The effect of pre-morbid height and weight on the survival of breast cancer patients.

Bakgrunn: Resultater fra studie 1 (Tretli 1989) viser at høyde og vekt er positivt assosiert med brystkreft. Studien indikerer at overvekt kan øke vekstraten i svulster i brystet. I denne studien ønsket man derfor å undersøke hvorvidt høyde og vekt kan ha prognostisk verdi. Resultater: I stadium I og II, hadde pasienter med høy BMI dårligere overlevelse enn pasienter med lav BMI, men BMI hadde ingen betydning for pasienter med avansert sykdom. Høyde ble ikke funnet å ha prog- nostisk verdi. Kommentarer: Studiens størrelse gjorde det mulig å analysere etter stadie, og resultatene støtter hypotesen om at høy BMI gir raskere sykdomsutvikling gjennom økt østrogen-eksponering. Studien har vært hyppig sitert i brystkreft-epidemiologisk forskning, spesielt innen diskusjonen om kostholdsintervensjon og vektreduksjon blant brystkreftpasienter. Antall siteringer: 21

Studie 11: Mohle BO \& Tretli S (1996) Pre-morbid body-mass-index in breast cancer: reversed effect on survival in hormone receptor negative patients.

Bakgrunn: Overvektige kvinner er funnet å ha større risiko for å dø av brystkreft. Formålet med denne studien var derfor å undersøke den prognostiske effekten av BMI i henhold til svulstenes reseptorstatus (østrogen/progesteron). Resultater: Overvektige pasienter med reseptor positive svulster hadde dårligst overlevelse. Effekten av BMI var omvendt når svulsten var reseptor negativ. Kommentarer: Studien inkluderte mer enn 1,200 brystkreft-pasienter hvor alle tilhørte ett og samme sykehus, og de kunne finnes igjen i høyde og vektfilen. Resultatene fører oss et steg videre i forhold til betydningen av vektrelatert hormoneksponering for progresjon av brystkreft. Det er et problem at det er vanskelig å finne tilsvarende datakilder i andre land som kan bekrefte våre funn. Antall siteringer: 18

Studie 12: Mochle BO, Tretli S, Skjoerven R, Thorsen $T$ (2001) Pre-morbid body weight and its relation to primary tumour diameter in breast cancer patients; its dependence on estrogen and progesteron receptor status.

Bakgrunn: Hormonelle mekanismer har vært brukt til å forklare at overvektige kvinner har høyere risiko for brystkreft, og oftere har mer avansert sykdom og dårligere prognose enn tynne. Denne studien undersøkte hvorvidt sammenhengen mellom BMI og svulststørrelse var påvirket av svulstenes reseptorstatus. Resultater: Pasienter med høy BMI hadde oftere reseptor positive svulster. Det ble også funnet en positiv sammenheng mellom BMI og svulststørrelse, hos pasienter med reseptor negative svulster. Kommentarer: Studien bygger videre på studie 11 (Mæhle \& Tretli 1996), og de assosiasjoner man observerte åpner for at også andre mekanismer enn de hormonelle må taes i betraktning når man skal forklare hvorfor høy BMI er assosiert med mer avansert sykdom. Det er en stor fordel at høyde og vektdatabasen, etablert på 1960-70-tallet, kan knyttes opp mot klinisk-patologiske data ved diagnosetidspunktet mange år senere (studie 10, 11 og 12). På denne måten eliminerer vi det problemet at sykdommen kan påvirke vekten. Antall siteringer: 3

\section{AVSLUTTENDE KOMMENTARER}

Formålet med å samle inn høyde- og vektdataene var å bruke de i en selektiv screening for tuberkulose. Kostnadene ved å drive et populasjons-basert kreftregister 
er fordelt på flere formål. Når man kobler disse to datakildene får man et godt grunnlag for interessant etiologisk forskning, til lavpris.

Disse studiene illustrerer hvordan etiologisk forskning kan påvise mulige biologiske sammenhenger og hvordan de kan definere områder hvor det er mulighet for mekanismeorienterte molekylærbiologiske studier. Studiene kan også indikere muligheter for forebyggen- de intervensjon. Med bakgrunn i disse studiene er høydevariabelen blitt spesielt interessant i diskusjonen om betydningen av tidlige leveår for kreftrisiko siden $\mathrm{i}$ livet.

Forskningen har foregått på avidentifiserte datafiler som betyr at personvernet er meget godt ivaretatt. Datatilsynet har vurdert og godkjent denne bruken av data.

\section{REFERANSER}

Akre O, Ekbom A, Sparen P, Tretli S. Body size and testicular cancer. J Natl Cancer Inst 2000; 92 (13): $1093-6$.

Bross IDJ. Pertinency of an extraneous variable. J Chron Dis 1967; 20: 487.

Engeland A, Tretli S, Bjørge T. Height, body mass index and prostate cancer: a follow up of 950,000 Norwegian men. Br J Cancer 2003; 89 (7): 1237-42.

Engeland A, Tretli S, Bjørge T. Height, body mass index and ovarian cancer: a follow up of 1.1 million Norwegian women. J Natl Cancer Inst 2003; 95 (16): 1244-8.

Ewertz M, Holmberg L, Tretli S, Pedersen BV, Kristensen A. Risk factors for male breast cancer - a case-control study from Scandinavia. Acta Oncol 2001; 40 (4): 467-71.

Grimsrud TK, Langseth H, Engeland A, Andersen Aa. Lung and bladder cancer in a Norwegian municipality with iron and steel producing industry: population based case-control studies. Occup Environ Med 1998; 55 (6): 387-92.

Harvei S, Tretli S, Langmark F. Quality of prostate cancer data in the Cancer Registry of Norway. Eur J Cancer 1996; 32A: 104-10.

Helseth A, Langmark F, Mørk SJ. Neoplasms of the central nervous system in Norway. Quality control of the registration in the Norwegian Cancer Registry. APMIS 1988; 96: 1002-8.

Helseth A, Tretli S. Premorbid height and weight as risk factors for development of central nervous system neoplasms. Neuroepidemiology 1989; 8 (6): 277-82.

Lund E. Pilot study of the evaluation of completeness of reporting to the Cancer Registry. In: Incidence of cancer in Norway 1978. The Cancer Registry of Norway, Oslo, 1981: 11-5.

Mork J, Thoresen SØ, Faye-Lund H, Langmark F, Glattre E. A study of the quality of the Cancer Registry of Norway's data on head and neck cancer for the period 1953-1991. APMIS 1995; 103: 375-82.

Mæhle BO, Tretli S. Pre-morbid body-mass-index in breast cancer: reversed effect on survival in hormone receptor negative patients. Breast Cancer Res Treat 1996; 41 (2): 123-30.

Mæhle BO, Tretli S, Skjærven R, Thorsen T. Pre-morbid body weight and its relation to primary tumour diameter in breast cancer patients; its dependence on estrogen and progesteron receptor status. Breast Cancer Res Treat 2001; 68 (2): 159-69.

Pott P. Chirurgical Obervations. Hawes, Clarke \& Collins, London, 1775 (Reprod: Natl Cancer Inst 1963, Monogr. 10: 7-13).

Robsahm TE, Tretli S. Height, weight and gastrointestinal cancer, a follow-up study in Norway. Eur J Cancer Prev 1999; 8 (2): 105-13.

Thune I, Olsen A, Albrektsen G, Tretli S. Cutaneous malignant melanoma: association with height, weight and body-surface area. A prospective study in Norway. Int J Cancer 1993; 55 (4): 555-61.

Tretli S. Height and weight in relation to breast cancer morbidity and mortality. A prospective study of 570,000 women in Norway. Int $J$ Cancer 1989; 44 (1): 23-30.

Tretli S, Magnus K. Height and weight in relation to uterine corpus cancer morbidity and mortality. A prospective study of 570,000 women in Norway. Int J Cancer 1990; 46 (2): 165-72.

Tretli S, Haldorsen T, Ottestad L. The effect of pre-morbid height and weight on the survival of breast cancer patients. Br J Cancer 1990; 62 (2): 299-303.

Tretli S, Robsahm TE. Height, weight and cancer of the oesophagus and stomach: a follow-up study in Norway. Eur J Cancer Prev 1999; 8 (2): 115-22.

Veierød MB and Laake P. Measurement error in prospective cohort studies of dietary fat intake and cancer: Bias in category specific incidence rate ratio estimates. In: Veierød MB, ed. Malignant melanoma, lung cancer and prostate cancer in relation to diet, a Norwegian prospective study emphasizing fat intake and methodological issues of measurement errors. Section for medical statistics, University of Oslo, 2000. 